Acta vet. scand. $1973,14,464-473$.

From the Research Station of the Veterinary Institute, Skara, Sweden.

\title{
CEREBRO-CORTICAL NECROSIS (C.C.N.) IN CALF
}

AN EXPERIMENTAL REPRODUCTION OF THE DISEASE

\author{
By \\ Claes-Göran Lilja
}

LILJA, CIAAES-GöRAN: Cerebro-cortical necrosis (C.C.N.) in calf. An experimental reproduction of the disease. Acta vet. scand. 1973, 14, 464-473. - In four ruminant calves a state of thiamine deficiency was brought about with a thiamine antagonist, amprolium. Twice daily the calves were given Amprolmix $\mathbb{B}$ containing $25 \%$ amprolium through a stomach tube. The dosage was $350-500 \mathrm{mg} / \mathrm{kg}$ body weight daily during the entire experimental period. After 31 days the first calf showed fully developed symptoms; two other calves fell ill after another four and eight days respectively. The fourth calf was killed before the disease became clinically manifest. In all calves cerebrocortical necroses were found on histological examination. The clinical picture is described. It was similar to that in spontaneous C.C.N.

In the calves exhibiting fully developed symptoms a moderate rise was observed in the pyruvate kinase and a heavy rise in the creatine phosphokinase activity. On several occasions the total quantity of thiamine (free + phosphorylated) in the blood exceeded the upper normal limit without any extra supply of thiamine being given. Only on one occasion was a lowering observed, to a value just below the lower limit of normal variation.

cerebro-cortical necrosis; polioencephalomalacia; amprolium; thiamine; thiamine deficiency.

Cerebro-cortical necrosis (C.C.N.) is a disease of cattle and sheep with central nervous symptoms which was first described in the United Kingdom in 1959 by Terlecki \& Markson. Although it is known that under normal conditions ruminants can cover their requirement of vitamin $B_{1}$ by microbial synthesis in the 
rumen, it is now considered that thiamine deficiency must be a contributory causative factor of the disease. In the search for its aetiology, therefore, the interest has recently been focussed on studies of thiamine antagonists and the effect of thiaminases on the thiamine metabolism in ruminants.

The object of the present investigation was, by means of a thiamine antagonist, amprolium, to provoke a state of thiamine deficiency in ruminant calves and to study the clinical and bloodchemistry effects of the deficiency state, especially in respect of the enzymes creatine phosphokinase (CPK) and pyruvate kinase $(\mathrm{PK})$. Increased CPK activity in serum is seen in muscle injuries but elevated serum values have bcen reported also in central nervous diseases in sheep (Smith \& Healy 1968). PK is very active in cerebral tissue, in which it promotes the formation of adenosine tri-phosphate from energi-rich phosphoenol pyruvate and has a regulatory role in the relations between adenosine triphosphate and adenosine diphosphate. Elevated PK values indicate a serous disturbance of the carbohydrate metabolism.

\section{MATERIAL AND METHODS}

The experimental animals consisted of four weaned (ruminant) calves, of which two were of Swedish red- and white and two of Swedish Friesian breed. The calves weighed between 97 and $130 \mathrm{~kg}$ at the beginning of the experiment. The ration consisted of hay, calf concentraie and cereals. The animals were housed in boxes with straw litter bedding. Twice daily they were given Amprolmix * containing $25 \%$ amprolium with a stomach tube. Their weight was checked after a three-week experimental period, the quantity of amprolium then being adjusted so as to yield a daily dose of $350-500 \mathrm{mg} / \mathrm{kg}$ body weight during the entire experimental period. Blood samples were taken between 9 and 11 a.m. once a week. The analyses were carried out as soon as possible after sampling except in the case of thiamine, calcium and NEFA determinations, for which serum was frozen and kept at $-20^{\circ} \mathrm{C}$. Urine samples were collected sporadically for determination of glucose.

* Merck, Sharp \& Dohme Ltd. Generously provided by Erik Lindblom \& Co. 
The following analyses were used:

NEFA

Blood glucose and serum GOT

CPK and PK

$\mathrm{Na}, \mathrm{K}, \mathrm{Mg}, \mathrm{Ca}$

Thiamine

\section{RESULTS}

\section{Clinical picture}

During the first month of the experimental period no sign of disease was observed in the calves on clinical examination. However, the animals appeared dull and depressed during the latter part of the month, and their hair-coats were lustreless and rough. After 31 days fully developed symptoms were detected in calf I (13 hrs. after the last observation). The calf lay on its side and had generalized tonic spasms alternating with violent clonic spasms and trotting movements. There was pronounced nuchal spasm (opisthotonus) and nystagmus. The pupillar reflexes were normal. Rectal temperature $38.3^{\circ} \mathrm{C}$. Pulse rate $108 / \mathrm{min}$. Respiratory rate $14 / \mathrm{min}$. Urine sample negative in respect of glucose (Clinistics $\Theta$, Ames). After a couple of hours of observation the calf was put to death with Mebumal® (ACO, Stockholm, Sweden).

After 35 days calf II started to exhibit symptoms in the form of pronounced torpor, mild ataxia and signs of impaired vision. Five hrs. later the symptoms were aggravated. The calf now showed signs of muscular weakness and muscle tremor. It had difficulty in maintaining its balance and fell over on repeated occasions. No spasms, however, were observed. Thirty-six hrs. after the onset of the symptoms the calf was unable to rise and had tonic spasms in the extremities, spasm of the masticatory muscles, opisthotonos and severe nystagmus. Clonic spasm could be easily provoked. Temperature $38.2^{\circ} \mathrm{C}$, pulse rate $80 / \mathrm{min}$., respiratory rate $80 / \mathrm{min}$. Urine test negative in respect of glucose. The ealf was put to death with Mebumal@. 
Calf III started to exhibit symptoms after an experimental period of 39 days. The early sympioms were closely similar to those seen in calf II. Six hrs. after their onset the calf's condition had deteriorated. It lay on its side with tonic spasms in the extremities, opisthotonos and nystagmus. Temperature $38.8^{\circ} \mathrm{C}$, heart rate $100 / \mathrm{min}$., respiratory rate $44 / \mathrm{min}$. Urine test negative in respect of glucose. The calf was treated with a vitamin B compound, receiving $200 \mathrm{mg}$ thiamine i.m. and the same quantity i.v. After $2 \frac{1}{2}$ hrs. the calf had manifestly improved clinically and could rise and stand without falling over. Ten hrs. later it had further improved, but still exhibited nuchal rigidity and mild ataxia. The calf was put to death simultaneously with calf IV which exhibited mild ataxia and torpor as sole symptoms.

\section{Blood chemistry picture}

During the experimental period no pronounced changes in the CPK values occurred until the calves exhibited fully developed symptoms, when sharp rises were observed. The same applied to the PK values, though their rise was only moderate. As regards SGOT values a slight rise was observed in two of the calves after development of symptoms (Figs. 1-3).

A rise of the blood glucose values was observed in two of the calves at the time of onset of the symptoms.

On several occasions the total quantity of thiamine (free + phosphorylated) in the blood exceeded the upper normal limit (Fig. 5) without any supply of thiamine over and above the normal content in the feed. Only on one occasion was a lowered value observed, but this was just below the lower limit of the normal variation.

The $\mathrm{Na}, \mathrm{K}, \mathrm{Ca}$ and $\mathrm{Mg}$ values in the calves with symptoms did not differ significantly from those in clinically healthy calves of corresponding age (Table 1).

Ta ble 1. Sodium, potassium, magnesium and calcium in serum from clinically healthy calves (A) and calves with symptoms of C.C.N. (B).

\begin{tabular}{|c|c|c|c|c|c|c|c|c|}
\hline & \multicolumn{2}{|c|}{$\mathrm{Na} \mathrm{mg/100} \mathrm{ml}$} & \multicolumn{2}{|c|}{$\mathrm{K} \mathrm{mg} / 100 \mathrm{ml}$} & \multicolumn{2}{|c|}{$\mathrm{Mg} \mathrm{mg} / 100 \mathrm{ml}$} & \multicolumn{2}{|c|}{$\mathrm{Ca} \mathrm{mg/100} \mathrm{ml}$} \\
\hline & $\mathbf{A}$ & B & A & B & A & B & A & B \\
\hline & 3 & 7 & 32 & 7 & 113 & 9 & 113 & 9 \\
\hline$\overline{\mathbf{x}}$ & 349.6 & 345.6 & 19.3 & 18.4 & 2.3 & 2.3 & 10.7 & 11.2 \\
\hline $\mathbf{s}$ & 8.4 & 9.8 & 1.8 & 1.9 & 0.3 & 0.2 & 1.2 & 0.8 \\
\hline
\end{tabular}



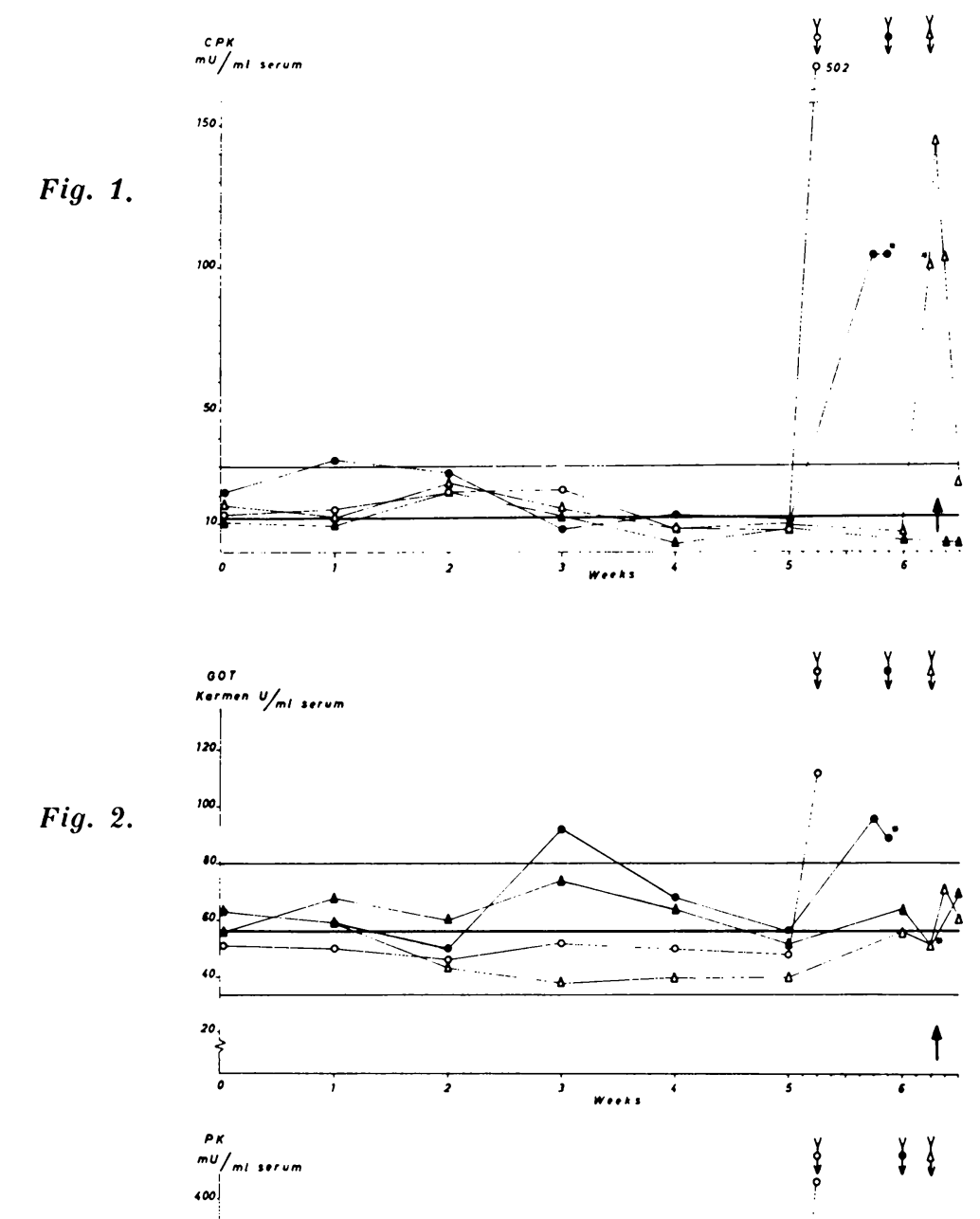

Fig. 3.

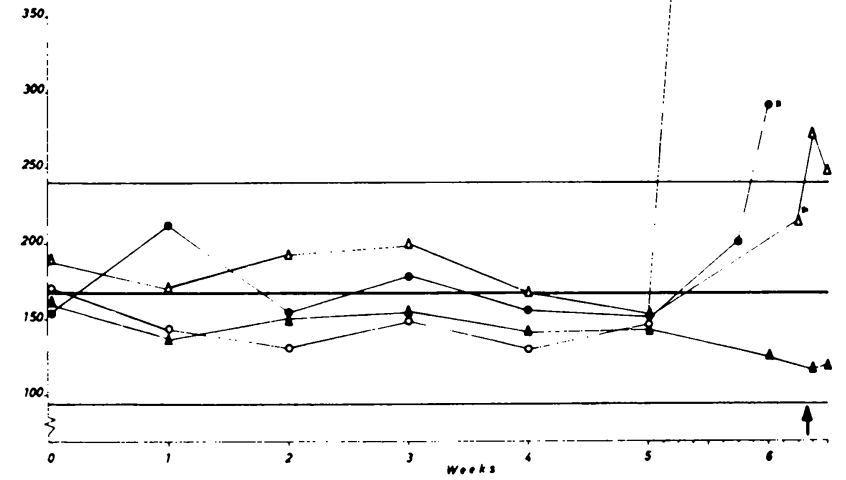


Fig. 4.

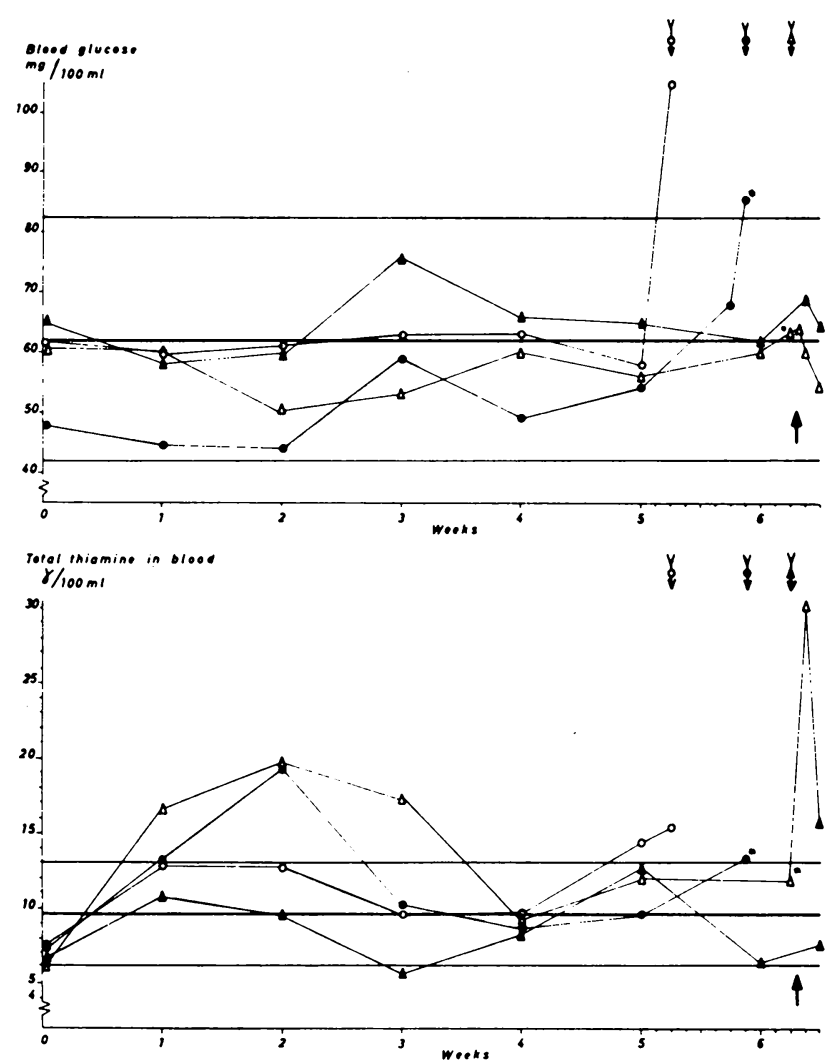

Figures 1-5. Rising arrow indicates treatment with thiamine. Descending arrow indicates time when each calf showed fully developed symptoms.

Key: $0=$ calf $I$

0 calf II

$\Delta=$ calf III

$\Delta=$ calf IV

* $=$ mean value of two analyses.

In conjunction with clinically manifest symptoms of C.C.N. there was a significant rise of NEFA above the normal values for clinical healthy calves of the same age (Table 2 ).

\section{Pathoanatomical picture}

On histological examination of the three calves with fully developed symptoms cerebro-cortical necroses typical of the disease (Terlecki \& Markson 1959, Lilja \& Krunajevic 1971) were 
T a ble 2. Non-esterified fatty acids (NEFA) in serum from clinically healthy calves (A) and calves with symptoms of C.C.N. (B).

\begin{tabular}{lll}
\hline & \multicolumn{2}{c}{ NEFA mmol/1 } \\
\cline { 2 - 3 } & $\mathrm{A}$ & $\mathrm{B}$ \\
\hline $\mathrm{n}$ & 32 & 7 \\
$\overline{\mathrm{x}}$ & 0.09 & 0.38 \\
$\mathrm{~s}$ & 0.5 & 0.30 \\
\hline & $\mathrm{t}=11.31^{* *}$
\end{tabular}

found in the brain and parakeratosis in the ruminal walls. The other parenchymatous organs showed no changes. The calf exhibiting only mild ataxia and torpor also had typical moderate focal cerebro-cortical necroses and parakeratosis in the rumen. Two of the calves (I and II) had subcutaneous oedema and small haemorrhages. In other respects the section was negative.

\section{DISCUSSION}

Smith \& Healy (1968) observed an elevated CPK activity in serum from sheep with histologically verified, spontaneous, socalled polioencephalomalacia. The SGOT activity, on the other hand, was only slightly increased. The same findings were made in the present study. In the calf treated with thiamine, however, the CPK value returned to normal within $36 \mathrm{hrs}$. The SGOT value was slightly elevated in the two calves in which subcutaneous oedema and haemorrhage were found at necropsy. These had presumably arisen through trauma in conjunction with the convulsive cramp attacks (Figs. 1 and 2 ).

Edwin (1970) reported heavily increased PK values in six spontaneous cases of C.C.N. in calves. This accords with the results in the present investigation, though the rises were not so large as in the spontaneous cases (Fig. 3). Edwin presumed that subclinical cases of C.C.N. would occur among calves and sheep in herds and flocks in which C.C.N. has occurred, and that such cases might possibly be detected by stuciy of variations in plasma enzymes, especially those which are thiamine-dependent. In the present investigation no rise in CPK or PK values was observed until the disease became clinically manifest. Nor was there any rise of the aforesaid enzymes in the calf (no. IV) which had only 
insignificant clinical symptoms, although cerebro-cortical necroses were found on histopathological examination. But it should be pointed out that the conditions may differ in spontaneous and provoked cases of C.C.N., and also that these two enzymes are not directly thiamine-dependent.

Serum determinations of $\mathrm{Ca}, \mathrm{Mg}, \mathrm{Na}$ and $\mathrm{K}$ in the calves exhibiting symptoms showed values within the normal range of variation (Table 1 ). This it not in accordance with a similar experimental study by Markson et al. (1966), which showed normal plasma potassium values up to two to seven days before death, when the values fell in three of four calves.

Daly (1968) reported a strongly positive reaction to glucose in the urine of two sheep with polioencephalomalacia. Urine samples from the calves exhibiting clinical symptoms in this study were negative in respect of glucose. The blood glucose values exceeded the normal limit in two of the calves (Fig. 4). This rise was probably due to an increased incretion of catecholamines in conjunction with the stress involved in the violent cramp attacks. A significant rise of the non-esterified fatty acids (NEFA) confirms this suspicion (Table 2).

Dietary thiamine deficiency does not give rise to the symptoms seen in cerebro-cortical necroses. Thiamine-deficient feed has been given to non-ruminant calves as from $48 \mathrm{hrs}$. after birth. No symptoms of C.C.N. were observed. Nor was the disease provoked after inactivation of thiamine with sodium sulphite (Edwin et al. 1968). It is well known that thiamine deficiency in other animal species is not associated with signs of blindness nor with cerebral injury of the kind seen in calves and sheep with C.C.N.

Thiamine is transported into the brain cells through a "carriermediated mechanism" dependent on the so-called sodium pump. It is known that amprolium may block this active transport of thiamine, probably through compelition for a membrane site (Sharma \& Quastel 1965). It is therefore possible that substances which block the thiamine transport into the brain cell can be supplied to or formed in the body and produce symptoms of thiamine deficiency without any thiamine deficiency existing in the blood. A heavily increased excretion of thiamine in the urine has been observed in calves receiving amprolium. Amprolium has also been isolated from the brains of such calves (Edwin, personal communication). It is therefore conceivable that amprolium displaces thiamine in the brain and that this might be a further 
explanation of the high blood-thiamine values and of the increased excretion via the kidneys. Amprolium does not interfere with the fluorimetric determination of thiamine in the blood (Edwin, personal communication).

The effect of amprolium on the uptake of thiamine in isolated small-intestinal cells from rats has been studied in vitro by $M e$ non \& Søgnen (1971). They showed that the total uptake of thiamine by the cells diminished with increase of the concentration of amprolium. The phosphorylation of thiamine was also inhibited. This accords with the findings from experiments with ligated intestinal loops (Polin et al. 1963). If this inhibition of the resorption of thiamine from the digestive tract takes place also in calves, it must be slight. It appears improbable that the body's reserves can cover the remaining thiamine requirements and at the same time give rise to elevated thiamine values in blood and urine.

The earlier mentioned inhibition of the active mechanism of transport into the brain cells may cause low thiamine values in the brain substance. It is not yet known which form of thiamine, free or phosphorylated, is essential for preservation of the normal nervous function (Steyn-Parvé 1967).

The suspicion of a thiamine deficiency in the brain cells as cause of the symptoms in the present investigation may be corroborated by the manifest clinical improvement after parenteral treatment with $400 \mathrm{mg}$ thiamine. But as the thiamine was administered in a vitamin B compound, the interpretation is uncertain. It has been possible to provoke C.C.N. with amprolium only in ruminants. No final explanation has been found hitherto for the mechanism by which amprolium exercises its injurious effect in ruminants. Even if the most likely explanation is an effect on the thiamine metabolism in the brain, it cannot definitely be ruled out that amprolium may have a neurotoxic effect of another kind.

\section{REFERENCES}

Daly, F. J.: Polioencephalomalacia: Response to thiamine treatment in sheep and a cow. Aust. vet. J. 1968, 44, 394.

Edwin, E. E.: Plasma enzyme and metabolite concentrations in cerebrocortical necrosis. Vet. Rec. 1970, 87, 396-398.

Edwin, E. E., G. Lewis \& R. Allcroft: Cerebrocortical necrosis: A hypothesis for the possible role of thiaminases in its pathogenesis. Vet. Rec. 1968, 83, 176-177. 
Laurell, S. \& G. Tibbling: Colorimetric microdetermination of free fatty acids in plasma. Clin. chim. Acta 1967, 16, 57-62.

Lilja, C. G. \& T. Krunajevic: Cerebro-cortical nekros hos kalv. (Cerebro-cortical necrosis in calves). Svensk Vet.-Tidn. 1971, 23, $526-532$.

Markson, L. M., S. Terlecki \& G. Lewis: Cercbrocortical necrosis in calves. Vet. Rec. 1966, 79, 578-579.

Menon, I. A. \& E. Søgnen: Amprolium and transport of thiamine in suspensions of intestinal cells. Acta vet. scand. 1971, 12, 111113.

Polin, D., E. R. Wynosky \& C. C. Porter: In vivo absorption of amprolium and its competition with thiamine. Proc. Soc. exp. Biol. (N.Y.) 1963, 114, 273-277.

Sharma, S. K. \& J. H. Quastel: Transport and metabolism of thiamine in rat brain cortex in vitro. Biochem. J. 1965, 94, 790-800.

Smith, J. B. \& P. J. Healy: Elevated serum creatine phosphokinase activity in diseases of the central nervous system in sheep. Clin. chim. Acta 1968, 21, 295-296.

Steyn-Parvé, E. P.: The mode of action of some thiamine analogues with antivitamin activity. Ciba Foundation Study Group 1967, No. 28, 26-41.

Terlecki, S. \& L. M. Markson: Cerebrocortical necrosis. Vet. Rec. 1959, $71,508$.

\section{SAMMANFATTNING}

Cerebro-cortical nekros (C.C.N.) hos kalv.

En experimentell reproduktion av lidandet.

Hos fyra idisslande kalvar framkallades ett tiaminbristtillstånd med hjälp av en tiaminantagonist, amprolium. Två gånger dagligen gavs kalvarna amprolmix $®$ innehållande $25 \%$ amprolium med strupsond. Doseringen var $350-500 \mathrm{mg}$ per $\mathrm{kg}$ kroppsvikt dagligen under hela försöksperioden. Efter 31 dagar visade den första kalven fullt utvecklade symptom, två andra kalvar insjuknade efter ytterligare fyra respektive åtta dagar. Den fjärde kalven avlivades innan sjukdomen var kliniskt manifest. Hos samtliga kalvar kunde cerebro-corticala nekroser påvisas vid histologisk undersökning. En beskrivning av den kliniska bilden ges. Den överensstämde med den vid spontan C.C.N.

Hos de kalvar som visade fullt utvecklade symptom iakttogs en måttlig stegring av pyruvatkinas- och en kraftig stegring av creatinphosphokinas-aktiviteten. Vid flera tillfällen översteg totalmängden tiamin (fritt + fosforylerat) i blodet den övre normalgränsen utan att någon extra tiamintillförsel hade skett. Endast vid ett tillfälle observerades en sänkning, till ett värde strax under nedre gränsen för normalvariationen.

(Received December 27, 1972).

Reprints may be requested from: C.-G. Lilja, Research Station of the Veterinary Institute, S-532 00 Skara, Sweden. 